\title{
人エナノカプセルによるカフェインの高選択的内包 カフェインをキャッチするカプセル分子
}

キサンチン骨格を有する有機化合物は自然界に幅広く 存在し，日常の飲料にも多く含まれている．たとえば, キサンチンの窒素上に3つのメチル基をもつカフェイン はコーヒーに，2つのメチル基をもつテオフィリンとテ オブロミンはそれぞれ，緑茶とココアに含まれることが 知られている(1) (図 1)。また，これらのキサンチン誘導 体は生体内でさまざまな薬理活性を示す(2).カフェイン の興奮・覚醒作用は古くから知られており，また，テオ フィリンは気管支拡張作用があるため, 今でも薬として 使われている．同じ有機分子骨格にもかかわらず，比較 的小さく, 分子間相互作用力の弱いメチル基 $\left(-\mathrm{CH}_{3}\right)$ の数や位置の違いにより, キサンチンの性質が大きく変 わる点は興味深い。

キサンチン化合物の薬理活性は, 生体内の比較的大き なタンパク質受容体により, 分子レベルで認識されるこ とで発現する. Marshallらは，カフェインと $\mathrm{A}_{2} \mathrm{~A}$ アデ ノシン受容体（分子量：約 $40 \mathrm{kDa}$ )の複合体の単結晶 を作製し，受容体の疎水性ポケットに1分子のカフェイ ンが内包されることをX線結晶構造解析より明らかに した (3) (図2)。また, その結晶構造から，複合体形成の 駆動力は分子間での踈水効果， $\pi$-スタッキング，水素結 合であることが示唆された。

一方，フラスコ内で，人工的な受容体によるキサンチ ン化合物の認識に関する研究も行われている. 2003年に Reinhoudtらは，4つのピリジニウム基を有する亜鉛ポ ルフィリンを合成し, 水中でカフェインなどの捕捉を達 成した ${ }^{(4)}$.この人工受容体は配位結合と疎水効果により, キサンチン化合物と複合体を形成したが，分子間相互作

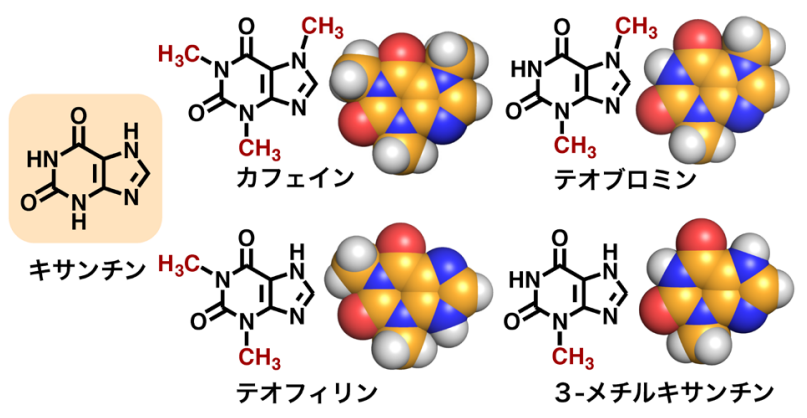

図1・キサンチン化合物とその立体構造

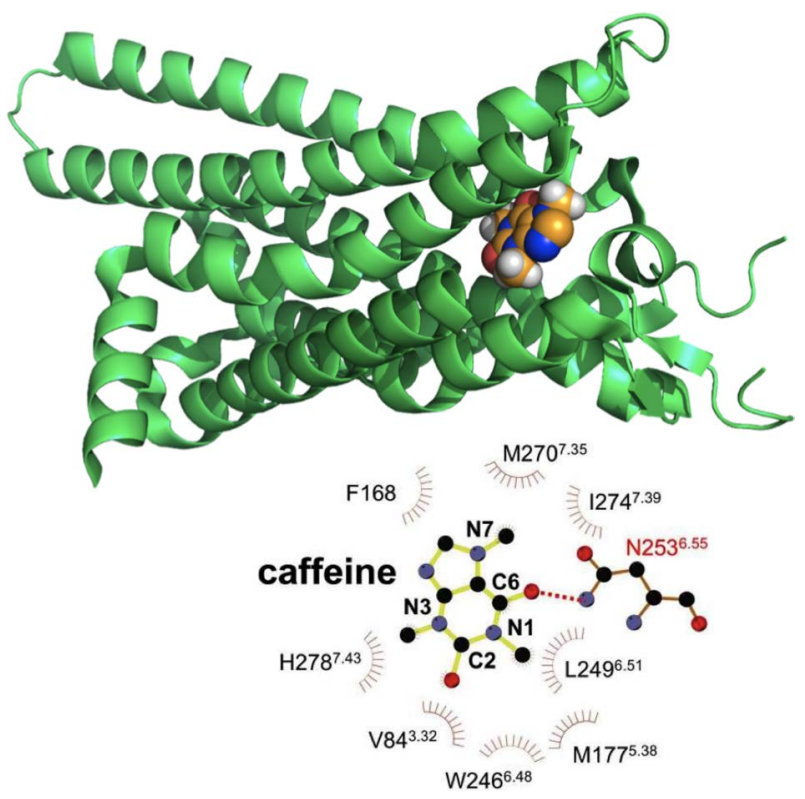

図 2『 $\mathrm{A}_{2} \mathrm{~A}$ アデノシン受容体の結晶構造

カフェインの内包掠よび分子間相互作用（下図は文献3より転写）.

用は弱く（結合定数： $K_{\mathrm{a}}=$ 約 $6 \times 10^{3} \mathrm{M}^{-1}$ ), 選択性な捕 捉能は示さない。また，2011年にSeverinらは，スルホ ネート基を含む蛍光性のピレン化合物を用いた, 飲料中 のキサンチン化合物の定量法を報告している(5). しかし ながら，弱い相互作用のため $\left(K_{\mathrm{a}}=\right.$ 約 $\left.3 \times 10^{2} \mathrm{M}^{-1}\right)$, 大 量の試料や煩雑な抽出作業が必要である。キサンチン誘 導体の効率的な捕捉や厳密な識別には, 生体受容体と同 様に, 数ナノサイズの疎水空間を有する三次元構造体の 合成が必要である、本稿では, 筆者らの最近の研究成果 として，有機配位子と金属イオンの自己集合によって形 成した人工ナノカプセルを利用し，水中でカフェインの 高選択的な内包に成功したので紹介する(6).

筆者らの研究グループでは, 数ナノメートルサイズの 空間を有する分子カプセルやチューブの構築と機能の開 発を行っている. 2011年に, 2つのアントラセン環を含 む湾曲型の有機配位子と金属イオン（パラジウムや白金 など）の自己集合により， $\mathrm{M}_{2} \mathrm{~L}_{4}$ 組成の人工ナノカプセ ルの合成に成功した(7) (図3)。このカプセルは, 8つの アントラセン環で囲まれた約 $1 \mathrm{~nm}$ の内部空間を有し, 


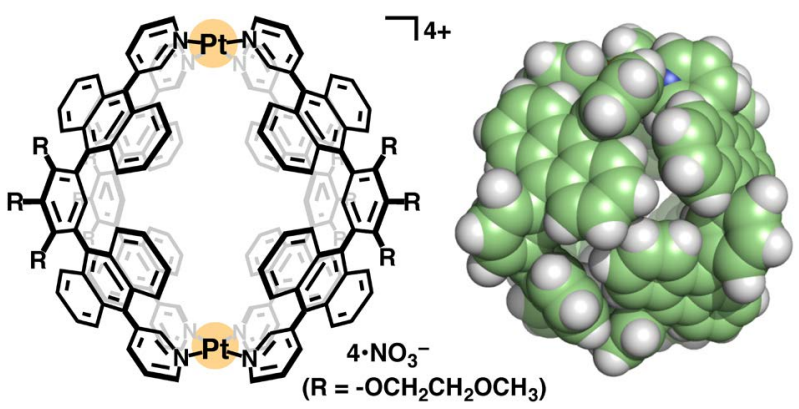

図3・人工ナノカプセルとその結晶構造

空間充填モデル表示の結晶構造は, カプセルの外面官能基 $(\mathrm{R})$ を 省略.

ピレンやBODIPY，フラーレン $\mathrm{C}_{60}$ などの疎水性有機分 子を水系溶媒中で, 効率的に内包することができる ${ }^{(7,8)}$. また，ポリマー合成に使われる高活性なラジカル開始剂 （AIBNなど）は，ナノカプセルに内包されることで, 光照射や加熱に対して顕著に安定化されることを見いだ した ${ }^{(9)}$. そこで，この生体受容体より小さなナノカプセ

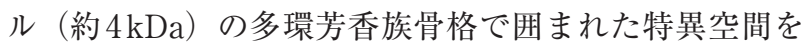
利用して，水中でのキサンチン類の選択的な内包を目指 した.

まず，白金イオンで架橋したナノカプセルを溶解した 水溶液 $\left(\mathrm{D}_{2} \mathrm{O}\right)$ に, 2 当量のカフェインを加え, 室温で 30 分間摚拌した。 その結果，カプセルに2 分子のカフェ インが定量的に取り込まれることが明らかになった．核 磁気共鳴装置 ( $\left.{ }^{1} \mathrm{H}-\mathrm{NMR}\right)$ による生成物のスペクトルで

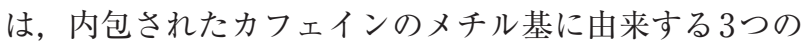
シグナルが，大きくシフトして観測された。 また，それ ぞれのシグナル面積の比較と生成物の質量分析（ESITOF MS）などにより，2分子のカフェインがナノカプ セルに強く内包されていることを明らかにした $\left(K_{\mathrm{a}}=>10^{8} \mathrm{M}^{-2}\right)$.

次に, 1 3つのメチル基を有するキサンチン化合物 （図1）を用いて，ナノカプセルによる内包の競争実験 を行った。ナノカプセルの水溶液に, 等量のカフェイン とテオブロミンを加えたところ，前者が選択的 （>99\%）に内包されることが, ${ }^{1} \mathrm{H}-\mathrm{NMR}$ およびESITOF MS解析で明らかになった（図4aの右側と $4 \mathrm{~b}$ ). また，2つのメチル基をもつテオブロミンとテオフィリ ンの競争実験では, どちらも同じ比率でカプセルに内包 された.ささらに，テオブロミンと3-メチルキサンチンの 競争実験では，前者が選択的（>99\%）に内包された a)

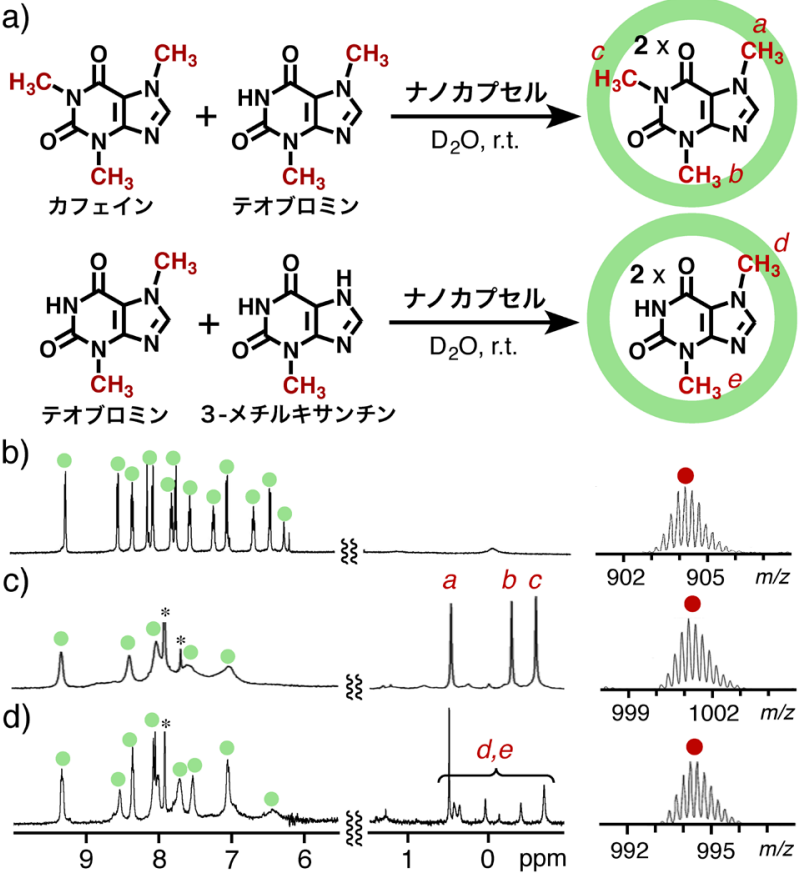

図4 ・ナノカプセルによる内包の競争実験

（a，上部； c） カフェインの選択的内包とその ${ }^{1} \mathrm{H}-\mathrm{NMR}$ およびESITOF MSスペクトル（緑丸；ナノカプセル), (b) 空のナノカプ セルの ${ }^{1} \mathrm{H}-\mathrm{NMR}$ およびESI-TOF MSスペクトル，(a，下部； d ) テオブロミンの選択的内包とそのスペクトル。

(図4aの左側と 4c)，すなわち，ナノカプセルは，キサ ンチン骨格に含まれるメチル基の数を厳密に認識して,

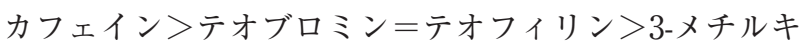
サンチンの順位で明確にこれらの分子を識別できること を明らかにした。

分子間相互作用の詳細を解明するため, 内包体の X 線結晶構造解析を行った. カフェインを内包した生成物 の溶液を, 室温でゆっくり濃縮することで (約 2 カ), 黄色透明の結晶が得られた。 その構造解析の結果, ナノ カプセル内に 2 分子のカフェインが重なり合って完全に 内包されていることが明らかになった (図 $5 \mathrm{a} \sim \mathrm{c}) . ま$ た，その 2 分子は，カプセル骨格の 2 つアントラセン 環に挟まれていた（図5b)。それらの面間距離は約 $3.4 \AA$ であった。 また，注目すべきことに，2分子のカ

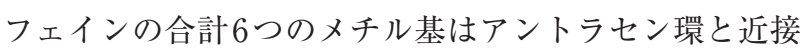
し(約 $3.5 \AA$ ),, $\mathrm{CH}_{3}-\pi$ 相互作用の存在が示唆された（図 5d). 一方，2分子のテオブロミンを内包したナノカプ セルの結晶構造では，4つのメチル基が $\mathrm{CH}_{3}-\pi$ 相互作用 していた．内包の駆動力は，ホストーゲスト間の疎水効 


\section{今日の話題}
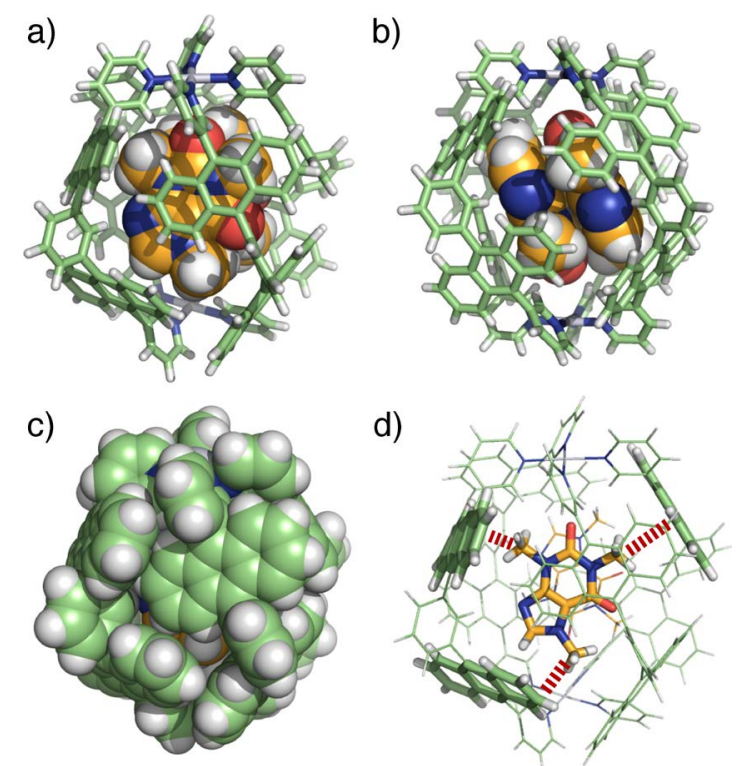

図5ロカフェインを内包したナノカプセルの結晶構造

(a, b) シリンダー表示のナノカプセルと空間充填モデル表示のカ フェイン（前および横向き), (c) 空間充填モデル表示, (d) メチ ル基とアントラセン環の $\mathrm{CH}_{3}-\pi$ 相互作用.

果および $\pi$-スタッキングであるが，この分子間 $\mathrm{CH}_{3}-\pi$ 相 互作用の数の違いが，カフェインの高選択的な内包の最 大の要因と結論づけた.

本稿で紹介した厳密なメチル基の識別は，既報の人工 受容体で達成した例はなく，多環芳香族骨格で囲まれた 空間を有する本ナノカプセルに特有の機能である．最後 に，市販のインスタントコーヒーの水溶液に，ナノカプ セルを加えたところ，その複雑な混合物の中からでも， カフェインを選択的に内包できることが明らかになっ た。今後は，これらの知見を活かし，人工受容体によ る，複雑な分子骨格を有する生体関連化合物の選択的な 内包と高感度な検出法の開発に挑戦していきたい。
1) B. A. Weignberg \& B. K. Bealer: "The World of Caffeine," Routledge, 2001, pp. 235-265.

2) T. M. Chou \& N. L. Benowitz: Biochem. Physiol., 109C, 173 (1994).

3) F. H. Marshall et al.: Structure, 19, 1283 (2011).

4) D. N. Leinhoudt, R. Fiammengo, M. C. Calama \& P. Timmerman: Chem. Eur. J., 9, 784 (2003).

5) K. Severin, S. N. Steinmann, C. Corminboeuf, K. Severin \& S. Rochat: Chem. Commun. (Camb.), 47, 10584 (2011).

6) M. Yamashina, S. Matsuno, Y. Sei, M. Akita \& M. Yoshizawa: Chem. Eur. J., 22, 14069 (2016).

7) N. Kishi, Z. Li, K. Yoza, M. Akita \& M. Yoshizawa: J. Am. Chem. Soc., 133, 11438 (2011).

8) M. Yamashina, M. Sartin, Y. Sei, M. Akita, S. Takeuchi, T. Tahara \& M. Yoshizawa: J. Am. Chem. Soc., 137, 9266 (2015).

9) M. Yamashina, Y. Sei, M. Akita \& M. Yoshizawa: Nat. Commun., 5, 4662 (2014).

(松野 匠, 吉沢道人, 東京工業大学科学技術創成研究 院化学生命科学研究所)

プロフィール

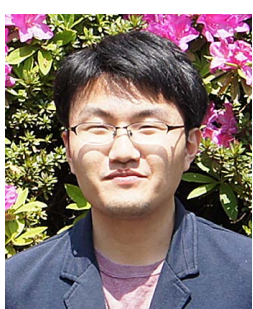

松野匠(Sho MATSUNO)

$<$ 略歴 $>2015$ 年東京理科大学理学部卒 業 $/ 2016$ 年東京工業大学大学院総合理工 学研究科修士課程在籍 $<$ 研究テーマと抱 負 >アントラセン環を有する金属架橋カプ セルの空間機能の探索 $<$ 趣味 $>$ 登山, 落語

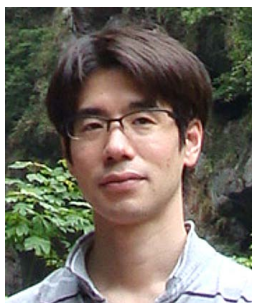

吉沢 道人 (Michito YOSHIZAWA)

$<$ 略歴 $>2002$ 年名古屋大学大学院工学研 究科博士課程修了 (工学博士) $/ 2003$ 年東 京大学大学院工学系研究科助手-助教 / 2008 年東京工業大学資源化学研究所准教 授 / 2016 年同科学技術創成研究院化学生 命科学研究所准教授 <研究テーマと抱負 $>$ 多環芳香族ナノ空間の機能創出 $<$ 趣味 $>$ 水 泳

Copyright (C) 2017 公益社団法人日本農芸化学会 DOI: 10.1271/kagakutoseibutsu.55.158 